\title{
A Role for Information Systems Education Programs
}

\author{
R. A. Hodgett \\ University of South Australia, Australia
}

alan.hodgett@unisa.edu.au

\begin{abstract}
The international media continually reports a worldwide shortage of skilled information technology literate people. An intermediary role or disciplinary area between business requirements and computer science has been identified in the past. A number of institutions have developed information systems education programs to fill this role. A survey of past graduates and employers evaluates the performance of several information systems education programs at the University of South Australia.
\end{abstract}

Keywords: information, systems, education, programs, graduates, employers

\section{Introduction}

The international media of developed and developing nations constantly reiterate the message that there is a massive shortage of persons with information technology (IT) and information systems (IS) skills. Education providers, from primary schools through to tertiary education institutions, and numerous private and company schemes, have been moving to supply market demand. A 1988 Delphi study in Australia was undertaken by (Watson, 1989) to research the problems facing the then IS managers and to alert those serving the IS community about where resources needed to be directed. In his report he identified the nexus between information technology and senior management and stated "If IT educators, professional societies, and researchers are to serve the IS community effectively, they must be aware of the key issues of IS managers. Educators need information on key concerns so that they may develop graduates with the necessary skills to solve these issues." (Ibid) In Australia a report (Department of Employment, Education and Training, 1992) on a review of computing studies and information sciences education identified a spectrum of relevant topics ranging from the pure science and engineering topics at one end of this spectrum to essentially business disciplines at the other end of the spectrum. The list of topics, though not exhaustive, identified engineering, computer systems engineering, computer science, information systems, commerce and business administration. Despite the number of information systems schools established worldwide (See websites in References) the field of information systems has faced, and still faces, a problem of recognition and acceptance as a legitimate disciplinary field within the tertiary education sector despite the number of information systems. The School of Information Systems at the University of South Australia was established to address this middle ground and had in place at that the time of the report several programs that addressed the nexus between computing science, engineering and technology and the requirements of organizations and management. It has continued to develop programs to meet the needs

Material published as part of these proceedings, either on-line or in print, is copyrighted by Informing Science. Permission to make digital or paper copy of part or all of these works for personal or classroom use is granted without fee provided that the copies are not made or distributed for profit or commercial advantage AND that copies 1) bear this notice in full and 2) give the full citation on the first page. It is permissible to abstract these works so long as credit is given. To copy in all other cases or to republish or to post on a server or to redistribute to lists requires specific permission from the publisher at publister@intormingscience.org of this intermediary role of marrying information technology to the needs business and administration. As part of the ongoing effort to improve the programs a project was undertaken to evaluate the quality of the IS programs as seen by the graduates themselves and in the eyes of industry employers.

A survey form was mailed to all graduates from the programs in the previous four years. The survey 
requested information on employment history, students' satisfaction with the aspects of programs and the achievement of the university's stated graduate qualities.

Managers identified by student responses as employers were interviewed and their responses to questions similar to those in the survey but adapted to the interview method were recorded. The findings of this survey of graduates from the IS programs in the last four years, and the results of the employer interviews, are presented in this paper to facilitate comparisons with similar programs in other institutions

\section{Responses}

Table 1 shows the employment pattern of respondents. A number of the graduates either continued in, or returned to, full time study.

\begin{tabular}{|c|c|c|c|}
\hline Full time & Part time & Full time study & Unemployed \\
\hline $83.33 \%$ & $2.38 \%$ & $11.90 \%$ & $2.38 \%$ \\
\hline
\end{tabular}

Table 1. Employment pattern of respondents

The survey of the graduates sought to investigate their views of two broad areas; the practical skills and employability of graduates and the development of long term personal qualities. In examining the practical skills and employability aspects of the responses two groups became evident, those graduates that had commenced their studies straight from secondary schools and thus had no extensive work experience, and those that had returned to either full time or part time education from existing employment positions.

An analysis of responses from those graduates that had commenced their studies straight from high school yielded no surprising results. A dominant issue was the employment opportunities offered by the programs. The majority of this group found employment within less than one month of seeking employment and with less than five interviews. A number of students involved in industry placements received job offers before completing the program. The positions offered were consistent with the practical skills acquired in the program such as programmer, programmer/analyst, business analyst, web designer and various titles including the word consultant. The commencing salaries reflected the lack of previous experience with the majority in the range from $\mathrm{A} \$ 30,000$ to $\mathrm{A} \$ 45,000$, which represents a premium on average starting for all new graduates. Employers confirmed the type of positions offered and this starting salary range. Advancement for the longer employed reflects a move to more responsible positions and increases in salaries. Responses to questions that related to skills in the programs that were deemed useful, weaknesses in the programs and other general comments are discussed later in the paper but in summary were reflected a demand for practical skills that lead to job opportunities and job advancement.

Those graduates that had returned to either full time or part time education from existing employment positions showed a different set of characteristics. Positions reported at the time of graduation include auditor, business coordinator, various management position and specialist occupational positions. Their concerns were for skills that broadened and complemented their existing experience and would therefore enhance their advancement opportunities. All showed advancement toward more senior management positions with associated increases in salaries. Of this group only one had changed employers since graduation.

Only a small percentage of all the respondents indicated that their program of study did not provide at least appropriate industry related knowledge and skills for use in their employment. Table 2 shows that thirty percent agreed that the program was adequate while approximately two thirds rated the programs as good or excellent in this respect. All employers interviewed rated the skills at least adequate while fiftysix percent rated the skills acquired good or excellent. 
The survey requested both graduates and employers to detail which skills in the programs they believed were useful or those they believed were missing and invited them to make any comments they considered would be helpful in assisting the university in providing or improving high quality education programs in information systems. Table 3 shows an edited list of skills identified by respondents as useful. These are ranked from most frequently identified to least frequently identified. It can be observed that there is considerable overlap in the skills identified by each group. For the students systems analysis and design skills headed the list closely followed by teamwork on projects, database concepts and design, programming and industry placements while for employers communications rated highest followed by good technical knowledge. However, all the skills in the listed were highly regarded and, it must be said, are skills that one would expect in a business oriented information systems programs. It is evident that the practical information systems skills and associated linkage to real business experience were appreciated.

\begin{tabular}{|l|l|}
\hline \multicolumn{1}{|c|}{ GRADUATES } & \multicolumn{1}{|c|}{ EMPLOYERS } \\
\hline Systems analysis and design & Communication skills \\
\hline Teamwork experience & Good technical knowledge \\
\hline Database concepts and skills & Knowledge of programming \\
\hline Programming & Project life cycle skills and knowledge \\
\hline Industry placements & Project management \\
\hline Oracle & General commercial awareness \\
\hline Presentation skills & Industry placement experience \\
\hline Communication skills & Knowledge of current IT/IS trends \\
\hline The blend of business and technical skills & Knowledge of large IT systems packages \\
\hline Case studies & Report writing \\
\hline Report writing skills & Web enabling \\
\hline Ability to think logically & \\
\hline Problem solving skills & \\
\hline Project management & \\
\hline
\end{tabular}

Table 3. Useful program skills in frequency of comment order.

In many instances the skills identified by the graduates as missing from the programs were advanced skills or more emphasis on those skills already identified as being useful in table 3 . The edited results of those skills nominated as missing are shown in table 4. As can be seen twelve of the seventeen categories of comments simply request more advanced or in depth coverage of skills already addressed in the programs. Of the five remaining categories only one, object oriented methodologies, was a skill normally associated with information systems or information technology. The remaining four, human dynamics, how to move "up" at work, teaching and encouragement to become self-employed and real world practices/issues, were more aspects of personal development. Of particular interest is the identification of human dynamics as an area of weakness expressed as a need to know how to deal with clients, to understand 
Role for Information Systems Education Program

different personality types, for more humanities courses, for help in obtaining a first job, for negotiation skills and for interpersonal skills. Employers only identified four weaknesses. These were "business savvy", technical skills, data communications and an understanding of ISO standards. The programs do try to provide some "business savvy" through the use of case studies and industry placements while the appearance of technical skills is somewhat at odds with the results displayed in table 3 above.

\begin{tabular}{|l|}
\hline Human dynamics \\
\hline Real world practices/issues \\
\hline Advanced Excel and Access \\
\hline Advanced Oracle \\
\hline How to move “up" at work \\
\hline Lacked teaching and encouragement to become self-employed. \\
\hline More depth in IT - networking, desktop, programming etc. \\
\hline More development of problem solving/trouble shooting skills. \\
\hline More emphasis on project management \\
\hline More emphasis on project style work \\
\hline More emphasis on short term marketable skills \\
\hline More on international business and culture awareness \\
\hline More on practical IT skills \\
\hline More on self expression and communication \\
\hline More use of industry experts to present specific industry topics and examples. \\
\hline More work experience \\
\hline Object oriented methodologies \\
\hline
\end{tabular}

Table 4. Skills identified as missing from programs.

The comments offered by graduates in response to the request for such feedback that would assist the university to provide or improve high quality education programs in information systems are summarized in Appendix A. It can be seen that they complement the identification of useful skills and weaknesses in the programs. The comments confirm the concern with practical skills, in particular programming, that provide a basis for employment. There is also recognition of the need for industry experience as well as knowledge of business and interpersonal skills.

This university recognizes the interests of students, professional associations, employers and the community and has defined a set of seven graduate qualities formulated to serve these interests. The final part of the survey sought the views of graduates and employers on the development of long-term personal qualities. The graduates were asked the extent, in their opinion, that their programs of study had contributed to the development of each graduate quality as well as their opinions on the need for formal qualifications and the length of time over which they would derive benefits from the programs. The results are shown in table 5. The contribution of the programs to the graduate qualities was rated very highly. There was only one quality where a small percentage of respondents indicated no contribution from the programs. For each of the qualities more than $70 \%$ of the responses indicated the contribution of the programs as moderate or high 


\begin{tabular}{|l|l|l|l|l|}
\hline & High & Moderate & Low & Nil \\
\hline $\begin{array}{l}\text { Operates effectively with and upon a body of knowl- } \\
\text { edge of sufficient depth to begin professional practice; }\end{array}$ & $29.27 \%$ & $63.41 \%$ & $7.32 \%$ & $0.00 \%$ \\
\hline $\begin{array}{l}\text { Is prepared for life-long learning in pursuit of personal } \\
\text { development and excellence in professional practice; }\end{array}$ & $46.34 \%$ & $46.34 \%$ & $7.32 \%$ & $0.00 \%$ \\
\hline $\begin{array}{l}\text { Is an effective problem solver capable of applying } \\
\text { logical, critical, and creative thinking to a range of } \\
\text { problems; }\end{array}$ & $29.27 \%$ & $70.73 \%$ & $0.00 \%$ & $0.00 \%$ \\
\hline $\begin{array}{l}\text { Can work both autonomously and collaboratively as a } \\
\text { professional; }\end{array}$ & $63.41 \%$ & $34.15 \%$ & $2.44 \%$ & $0.00 \%$ \\
\hline $\begin{array}{l}\text { Is committed to ethical action and social responsibility } \\
\text { as a professional and citizen; }\end{array}$ & $36.59 \%$ & $36.59 \%$ & $24.39 \%$ & $2.44 \%$ \\
\hline $\begin{array}{l}\text { Communicates effectively in professional practice and } \\
\text { as a member of the community; }\end{array}$ & $36.59 \%$ & $58.54 \%$ & $4.88 \%$ & $0.00 \%$ \\
\hline $\begin{array}{l}\text { Demonstrates an international perspective as a profes- } \\
\text { sional and as a citizen. }\end{array}$ & $19.51 \%$ & $65.85 \%$ & $12.20 \%$ & $0.00 \%$ \\
\hline
\end{tabular}

Table 5. Graduates: Contribution to graduate qualities.

In interviews with the employers they were asked to what extent they believed the graduates they employed had each of the graduate qualities. The results are shown in table 6. Again the achievement of the qualities was generally rated moderate or high. The two major exceptions are quality five, "Is committed to ethical action and social responsibility as a professional and citizen", where some twenty-seven percent rated achievement as low or nil and quality seven, "Demonstrates an international perspective as a professional and as a citizen", where twelve percent rated achievement as low. Interestingly the poorer response to these two qualities is reflected in the graduate responses above. These particular results are disappointing and will merit some deeper examination of the programs.

Both groups were asked if, in general, they considered the formal programs of study to have been worthwhile. All respondents signified that it had been. While there is always room for improvement the overall

\begin{tabular}{|l|l|l|l|l|}
\hline & High & Moderate & Low & Nil \\
\hline $\begin{array}{l}\text { Operates effectively with and upon a body of knowl- } \\
\text { edge of sufficient depth to begin professional practice; }\end{array}$ & $57.14 \%$ & $42.86 \%$ & $0.0 \%$ & $0.00 \%$ \\
\hline $\begin{array}{l}\text { Is prepared for life-long learning in pursuit of per- } \\
\text { sonal development and excellence in professional } \\
\text { practice; }\end{array}$ & $42.86 \%$ & $42.86 \%$ & $14.29 \%$ & $0.00 \%$ \\
\hline $\begin{array}{l}\text { Is an effective problem solver capable of applying } \\
\text { logical, critical, and creative thinking to a range of } \\
\text { problems; }\end{array}$ & $85.71 \%$ & $14,29 \%$ & $0.00 \%$ & $0.00 \%$ \\
\hline $\begin{array}{l}\text { Can work both autonomously and collaboratively as a } \\
\text { professional; }\end{array}$ & $100.0 \%$ & $0.0 \%$ & $0.0 \%$ & $0.00 \%$ \\
\hline $\begin{array}{l}\text { Is committed to ethical action and social responsibility } \\
\text { as a professional and citizen; }\end{array}$ & $42.86 \%$ & $28.57 \%$ & $28.57 \%$ & $0.0 \%$ \\
\hline $\begin{array}{l}\text { Communicates effectively in professional practice and } \\
\text { as a member of the community; }\end{array}$ & $100.0 \%$ & $0.0 \%$ & $0.0 \%$ & $0.00 \%$ \\
\hline $\begin{array}{l}\text { Demonstrates an international perspective as a profes- } \\
\text { sional and as a citizen. }\end{array}$ & $0.0 \%$ & $57.14 \%$ & $42,86 \%$ & $0.00 \%$ \\
\hline
\end{tabular}

Table 6. Employers: Achievement of graduate qualities. 
Role for Information Systems Education Program

opinion is one that positive support for the programs.

Both groups were further asked whether, in general, having been in contact with other people in the industry, they believed formal qualifications are necessary in order to gain meaningful and rewarding employment. Table 7 shows that while most felt that such qualifications were necessary some fifteen percent of graduates and forty-three percent of employers indicated their belief that they were not.

This latter result reflects anecdotal evidence from industry that experience is of prime importance and employers' willingness to hire on the basis of experience but this is counterbalanced by a student view that it is increasingly difficult to gain experience without a formal qualification.

\begin{tabular}{|l|l|l|}
\hline & Yes & No \\
\hline Graduates & $85.00 \%$ & $15.00 \%$ \\
\hline Employers & $57.00 \%$ & $43.00 \%$ \\
\hline
\end{tabular}

Table 7. Are formal qualifications necessary?

The feeling is also reflected in the opinions on the length

of time that benefits of the programs would last and in comments on strengths and weaknesses reported below in Appendix A. Some $40.5 \%$ of graduates and $28.5 \%$ of employers recognized that benefits would last long term or for a lifetime. The remaining respondents indicated that they believed that the benefits lasted only a few years, mainly in gaining initial employment and that from then onwards the primary factors in future employment and advancement lay in experience gained and performance. In view of the response relating to the contribution of the programs to the graduate qualities, qualities that have inherent long term implications; the number of responses indicating only a short-term benefit from the programs is a little surprising.

\section{Summary}

The results of this survey indicate a consensus of opinion between graduates and employers on the qualities of the programs involved. In summary the views held by graduates of these information systems programs, and employers, are that they provided a good foundation of relevant and information skills that provide an acceptable springboard into business. Comments solicited under the headings of useful skills, missing skills and other comments generally reflect the demand for practical skills that lead to job opportunities and job advancement. Aspects of the education programs that were considered useful were work placements, programming languages, database skills, a knowledge of Oracle products and systems design and analysis knowledge. Listed as missing were more advanced work in these skills, more project work and project management skills, human dynamics and real world or hands on experience. There was strong support for the proposition that the programs contributed significantly to the long-term qualities of graduates. The programs are under continual review, this survey being part of the process, and while there is always room for continuing improvement and adaptation it would appear that from both graduates and employers regard the programs as having been successful to date. The results also provide further support for the intermediary business role of information systems programs.

\section{References.}

Richard T. Watson, Key Issues in information systems management: An Australian perspective - 1988, The Australian Computer Journal, Vol. 21, No. 2, August 1989.

Report of the Discipline Review of Computing Studies and Information Sciences Education, Department of Employment, Education and Training, Australian Government Publications Service, Canberra, 1992.

See for example schools offering programs in IS at ISWORLD NET Top Resources, IS Faculty Directory at UML: hitp://webioot.csom.umn.edu/iswortd/acdir/delault.htmp or Graduate IS Programs at

http://WWW.pitt.edu/ 1sprogs/graduate.htm 


\section{Biography}

HODGETT, R. Alan. MCA, BCA, BA is a senior lecturer at the University of South Australia, Australia

Spent the first part of the working career as a telecommunications engineer with the Automatic Telephone and Electric Company, England. Moved to New Zealand in the mid 1950's and worked with the New Zealand Post Office in the engineering branch. In the late 1960's transferred to the Electronic Data Processing Division as a programmer and then analyst. Joined Victoria University of Wellington, New Zealand in 1974. Moved to Australia in 1989 and joined the University of South Australia.Current research interests lie with data management in organizations and the development of effective information systems.

\section{Appendix A.}

\section{Comments offered by graduates to assist the university to improve the education programs in in- formation systems.}

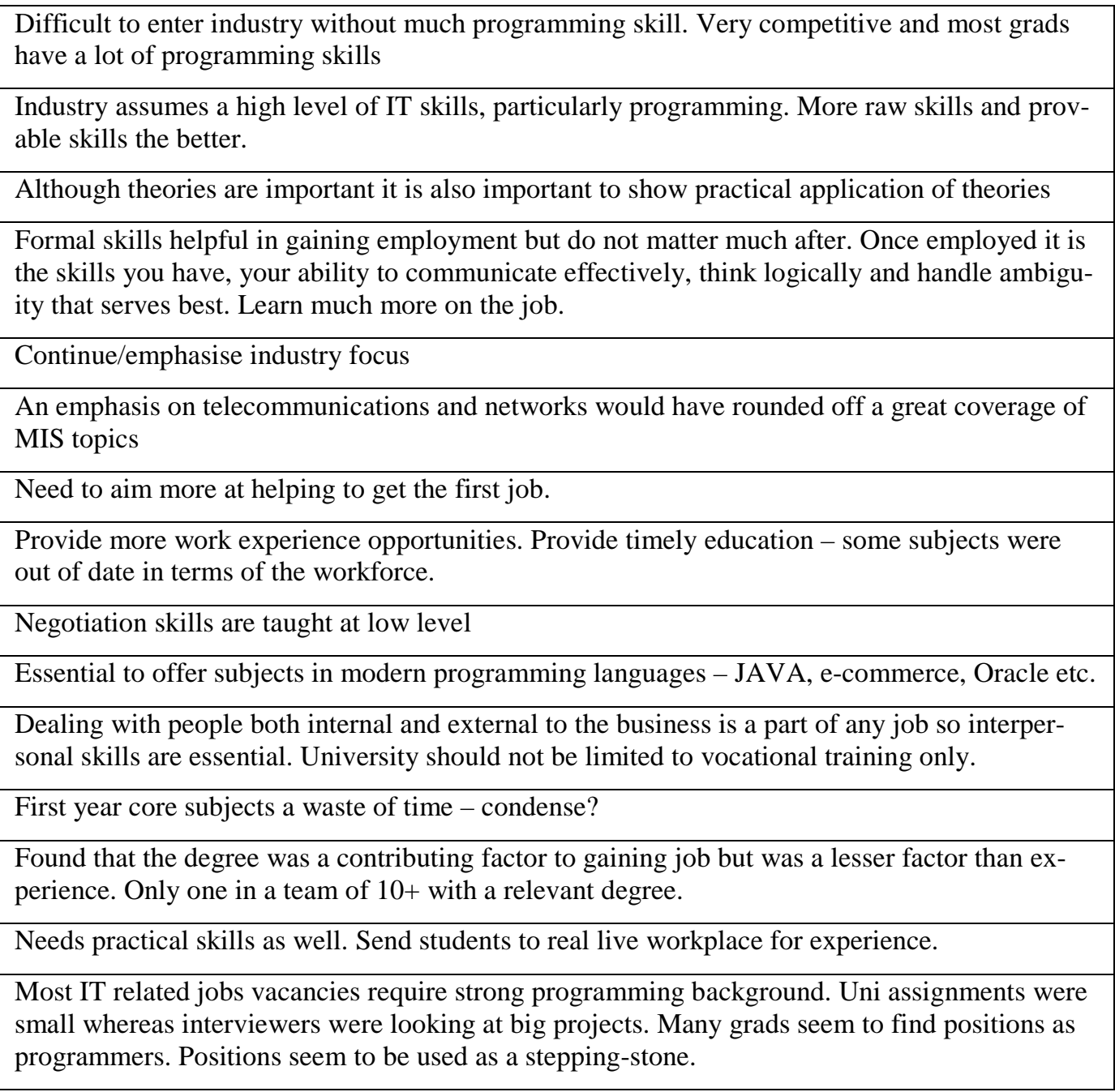

